\title{
Effect of method of preservation on the chemical composition of Enterolobium
} cyclocarpum leaves

${ }^{* 1}$ Ekanem, N. J., ${ }^{2}$ Okah, U. ${ }^{2}$ Ahamefule, F. O., ${ }^{1}$ Ifut, O. J., ${ }^{2}$ Ikwunze, K., ${ }^{1}$ Udoh, E. F., ${ }^{1}$ Edet, H. A. and ${ }^{1}$ Orok, A. M.

${ }^{\prime}$ Department of Animal Science, Faculty of Agriculture, University of Uyo, Uyo, Akwa Ibom State.

${ }^{2}$ Department of Animal Production and Livestock Management, College of Animal Science and Production, Michael Okpara University of Agriculture, Umudike, Abia State.

"Corresponding author: ekanem_n@yahoo.co.uk; 08038701314.

\section{Abstract}

Enterolobium cyclocarpum leaves are less acceptable by ruminants due to their high contents of anti-nutritional factors. The effect of preserving Enterolobium cyclocarpum leaves as hay and silage or silage: hay combinations on the proximate, fibre fractions, antinutritional factors, minerals and vitamins compositions were investigated in this study. Six experimental treatments consisting of 100\% fresh Enterolobium cyclocarpum leaves, 100\% ensiled Enterolobium cyclocarpum leaves, 100\% sun dried Enterolobium cyclocarpum leaves, $75 \%$ silage: 25\% hay, 50\% silage: 50\% hay and 25\% silage: $75 \%$ hay were formulated. Each treatment was replicated 3 times and analyzed for chemical composition. The crude protein content ranged from 14.70 - 22.05\%, which significantly differed $(p<0.05)$ across treatments with the highest value in the fresh leaves. The values for neutral detergent fibre ranged from $56.64-57.92 \%$, acid detergent fibre from $37.14-39.87 \%$ and acid detergent lignin from $13.30-14.96 \%$, they all differed significantly $(p<0.05)$ across treatments with highest values in the $100 \%$ ensiled treatment. Preservation as silage significantly $(p<0.05)$ reduced the concentrations of tannin, phytate and hydrocyanic acid, while preservation as hay significantly $(p<0.05)$ reduced the concentration of saponin. The mineral contents of the EC leaves preserved as silage, hay and silage: hay combinations (Treatments 2 - 6) compared favourably with the mineral contents of the fresh leaves (Treatment 1). Preserved EC leaves (Treatments $2-6)$ had significantly $(p<0.05)$ higher concentrations of vitamin $C(444.21-657.60 \mathrm{mg} / 100 \mathrm{~g})$ than the fresh leaves (308.79mg/100g). Thus preservation of E. cyclocarpum leaves as silage or hay improved its chemical composition and reduced its contents of anti-nutritional factors.

Keywords: Enterolobium cyclocarpum, chemical composition, ensiling, sun drying, mineral composition, vitamin contents.

\section{Introduction}

Enterolobium cyclocarpum is a species of flowering tree in the pea family Fabaceae. Guanacaste tree is native to the tropical regions of the Americas including Brazil, Colombia, Guyana, Mexico, United States of America and Venezuela (Wikipedia, 2018). Caro caro tree is also abundant in Guanacaste Province of Costa Rica. It is widespread in tropical parts of both Americas, in the Caribbean Islands and in
Florida, Puerto Rico, Cuba, Dominican Republic, Haiti, Jamaica and Hawaii (Wikipedia, 2018). It has been introduced into many other tropical areas of the world such as Nigeria, Sumatra, Indonesia, and Australia (Orwa et al., 2009; Wikipedia, 2018). Ear pod tree is naturally found in humid and sub humid regions especially in coastal areas and river banks (Andreu et al., 2015). Like other plants, both primary and secondary plant organic metabolites are 
present in Enterolobium plants. The primary compounds are directly involved in the plant's growth and development. On the other hand, plant secondary metabolites (PSM) are not directly involved in the plant's development or nutrition (Crozier et al., 2006). These less beneficial PSM are bioactive compounds/anti-nutritional factors (ANFs) which functions include protective defense mechanisms against pathogens, discouraging consumption by herbivorous animals, imparting some degree of toxicity to herbivores, altering the foraging behaviour of herbivores, affecting feed digestibility, nitrogen fixation in a symbiotic relationship with beneficial microorganisms and transportation of metals within the plant (Waghorn, 2008; Demain and Fang, 2000). These PSM include tannins, saponins, steroids, mimosine, coumarin, phenols, phytate, oxalate, hydrocyanide flavonoids, triterpenes, anthocyanidins, reducers and alkaloids (Galindo et al., 2014). The most abundant PSM are tannins and saponins. Tannins are bitter tasting plant polyphenols that bind and precipitate proteins. Tannins are usually grouped into two: hydrolysable tannins (HT) and condensed tannins (CT). Before now, it was generally claim that tannins and saponins are harmful and toxic to ruminant animals. However with the beneficial usage of tannins in drinks and foods for humans and the use of saponins in human diet for controlling cholesterol, ruminant's research nowadays focused on the use of these PSM either as extracts or whole plants to explore its potentials and risks (Broderick and Albrecht, 1997; Carulla et al., 2005; Soliva, 2007; Stewart, 2018). Enterolobium cyclocarpum leaf is rich in nutrients, containing $15.59-18.6 \%$ crude protein (CP), 8.16 - 48.2\% crude fibre (CF), $2.21-11.00 \%$ ether extract (EE), 4.90 - $11.80 \%$ ash, $51.4-63.94 \%$ neutral detergent fibre (NDF); 31.90 -
$42.99 \%$ acid detergent fibre (ADF), $8.6 \%$ acid detergent lignin (ADL) (Babayemi, 2006; Isah et al., 2011; Galindo et al., 2014; Aderinboye et al., 2016). However, its acceptability by ruminant is low due to its contents of ANFs (Koenig et al., 2007; Isah et al., 2011).

\section{Materials and methods}

The study was carried out at the Teaching and Research Farms, University of Uyo, Uyo, Akwa Ibom State, Nigeria. Uyo is located between latitudes $4^{\circ} 59^{\prime}$ and $5^{\circ} 04^{\prime}$ $\mathrm{N}$ and longitudes $7^{\circ} 52^{\prime}$ and $8^{\circ} 00^{\prime} \mathrm{E}$. Uyo is located within the tropical rainforest zone which characterizes the South South agroecological zone of Nigeria. The annual rainfall in Uyo ranges from $800 \mathrm{~mm}-3,200$ $\mathrm{mm}$ per annum. Rains begin in March and continue till October with peaks in June and September and two weeks of break in August (August break), then followed by dry season from November till February. Annual temperature varies between 23-28 ${ }^{0} \mathrm{C}$ (Ifut and Mbaba, 2014). The leaves of Enterolobium cyclocarpum were harvested and divided into three portions. One of the portions was taken immediately to the laboratory for chemical analyses. The second portion was ensiled while the third portion was sundried to hay. At the end of the ensiling and sun drying periods, representative samples of the ensiled and sundried Enterolobium cyclocarpum leaves were subjected to chemical analyses. Additionally, the ensiled and sundried leaves were mixed in different proportions to form experimental diets which were also analyzed for their chemical compositions. Enterolobium cyclocarpum leaves were ensiled in 4-liter mini silos. Individual leaves of EC (devoid of the petioles) were quickly packed into the silos lined with polythene bags. The mass was manually compacted to expel air. Further air expulsion was achieved by covering the 
mass with polythene bags and pressing down with sand bags. The silos were also covered using their lids. The ensiling lasted for 21 days. The fresh and treated (silage, hay and silage $\mathrm{x}$ hay combinations) Enterolobium cyclocarpum leaves were used to formulate six (6) sole and combined experimental treatments as follows:

Treatment 1: $\quad 100 \%$ fresh Enterolobium cyclocarpum leaves (FENT)

Treatment 2: $\quad \begin{array}{llllll}1 & 0 & 0 & \% & \text { e } & \mathrm{n} \mathrm{s} \\ \mathrm{i} & \mathrm{l} & \mathrm{e} \mathrm{d}\end{array}$ Enterolobium cyclocarpum leaves (ENENT)

Treatment 3: $\quad 100 \quad \% \quad$ s u n $\quad$ d ri e d Enterolobium cyclocarpum leaves (DENT) Treatment 4: $75 \%$ ensiled $+25 \%$ sun dried Enterollobium cyclocarpum leaves (ENENT 75)

Treatment 5: $\quad 50 \%$ ensiled $+50 \%$ sun dried Enterolobium cyclocarpum leaves (ENENT 50)

Treatment 6: $\quad 25 \%$ ensiled $+75 \%$ sun dried Enterolobium cyclocarpum leaves (ENENT 25)

The treated leaves were analyzed for proximate, fibre fractions, minerals, vitamins composition and anti-nutritional factors. Each treatment was replicated three times. Dry matter (DM), crude protein (CP), crude fibre (CF), ash, ether extract (EE) and Nitrogen free extract (NFE) were determined according to the method of AOAC (1990). The fibre fractions - neutral detergent fibre (NDF), acid detergent fibre (ADF) and acid detergent lignin (ADL) were determined using the procedures of Van Soest et al. (1991). Cellulose was calculated as the difference between ADF and ADL while hemicellulose was calculated as the difference between NDF and ADF. Tannins were determined by the Folin-Dennis Spectrophometric method (Pearson, 1976). The saponin content of the sample was determined by the Double Solvent Extraction Gravimetrical Method
(Harborne, 1973). Phytate was analyzed by the procedure of McCance and Widdowson (1953). Ammonia nitrogen $\left(\mathrm{NH}_{3} \mathrm{~N}\right)$ was determined by Nessler's Colorimeter Method (AOAC, 1990). The mineral contents were determined by the dry ash extraction method, following which specific mineral elements were analyzed. Phosphorus was determined by the vanadomolybdate (y e 11 ow) spectrophotometry method (AOAC, 1980). Calcium and magnesium were determined by the Versanale EDTA complexiometric titration method (Pearson, 1976). Potassium and sodium were determined by flame photometry (AOAC, 1990). Data obtained were subjected to analysis of variance using SAS (2000) Statistical software. Significant means were separated using Duncan Multiple Range Test of the same Statistical package.

\section{Results and discussion}

The proximate composition of fresh and treated EC leaves is shown in Table 1. Values obtained for dry matter (DM) were significantly different $(p<0.05)$ from each other. The values obtained for the fresh, ensiled and dried samples were 34.93, 38.56 and $93.35 \%$ respectively. Dry matter values for differently preserved EC leaves combinations were 49.75, 59.45 and $77.69 \%$ for diets 4 (ENENT 75), 5 (ENENT 50) and 6 (ENENT 25) respectively. The $34.93 \%$ DM for fresh EC leaves reported in this study is slightly lower than the value (39.08\%) reported by Babayemi (2006), slightly higher than the value $(32.15 \%)$ reported by Isah et al. (2011) and compares favvourably with the value of $34.40 \%$ reported by Aderinboye et al. (2016) for fresh EC leaves. The variation might be as a result of soil type, weather and differences in eco-climatic zone. The DM value of $93.35 \%$ for dried EC leaves obtained in this study also compares favourably with the 
value $(93.20 \%)$ reported by Koenig et al. (2007) for dried EC leaves. The crude protein contents obtained in this study which were significantly different $(\mathrm{p}<0.05)$ across treatment were $22.05 \%$ for the fresh EC leaves and values of $14.53-17.93 \%$ in treatments 2 to 6 . The CP values were within the range of values reported by other authors for EC leaves (Babayemi, 2006; Isah et al., 2011; Aderinboye et al., 2016) and the range of values $(13.65-31.51 \%)$ reported for other browse plants (Ahamefule et al., 2006; Asaolu et al., 2012; Isah et al., 2012; Ogunbosoye, 2013; Bassey et al., 2014; Galindo et al., 2014; Obua, 2014; Okpara et al., 2014; Oyedele et al., 2016). Olorunnisomo and Fayomi (2012) reported a similar CP of $21.1 \%$ for fresh EC leaves. The CP values obtained in this study was above the minimum $\mathrm{CP}$ value $(8 \%)$ required for effective rumen function (Norton, 1998). The range of CP values obtained in this study was also above the minimum protein requirement of $10-12 \%$ for ruminant animals (ARC, 1984). The CP $(14.70 \%)$ for the ensiled EC leaves is lower than the CP $(22.05 \%)$ for fresh EC leaves. This occurs because the soluble carbohydrates in EC leaves were not enough to favour effective fermentation. Additionally, the high buffering capacity of the leaves made them to resist changes in $\mathrm{pH}$, thus exposing the $\mathrm{CP}$ to proteolysis. This corroborates the findings of McDonald et al. (1995), Babayemi (2009), Falola et al. (2013) and Ekanem et al. (2017).

Table 1: Proximate composition (\% DM) of fresh and treated Enterolobium cyclocarpum leaves

\begin{tabular}{llllllll}
\hline Parameters & FENT & ENENT & DENT & ENENT 75 & ENENT 50 & ENENT 25 & SEM \\
\hline Dry matter & $34.93^{\mathrm{f}}$ & $38.56^{\mathrm{e}}$ & $93.35^{\mathrm{a}}$ & $49.75^{\mathrm{d}}$ & $59.45^{\mathrm{c}}$ & $77.69^{\mathrm{b}}$ & 5.06 \\
Crude protein & $22.05^{\mathrm{a}}$ & $14.70^{\mathrm{d}}$ & $17.85^{\mathrm{b}}$ & $14.53^{\mathrm{a}}$ & $16.22^{\mathrm{c}}$ & $17.93^{\mathrm{b}}$ & 0.62 \\
Crude fibre & $3.10^{\mathrm{f}}$ & $5.12^{\mathrm{b}}$ & $5.32^{\mathrm{a}}$ & $4.34^{\mathrm{c}}$ & $4.27^{\mathrm{d}}$ & $4.11^{\mathrm{e}}$ & 0.18 \\
Ether extract & $3.23^{\mathrm{e}}$ & $3.37^{\mathrm{d}}$ & $3.18^{\mathrm{f}}$ & $4.71^{\mathrm{a}}$ & $3.95^{\mathrm{c}}$ & $4.50^{\mathrm{b}}$ & 0.15 \\
Ash & $4.40^{\mathrm{f}}$ & $7.61^{\mathrm{b}}$ & $7.91^{\mathrm{a}}$ & $6.38^{\mathrm{c}}$ & $6.13^{\mathrm{d}}$ & $6.04^{\mathrm{e}}$ & 0.28 \\
NFE & $66.57^{\mathrm{e}}$ & $69.20^{\mathrm{c}}$ & $65.74^{\mathrm{f}}$ & $70.04^{\mathrm{a}}$ & $69.44^{\mathrm{b}}$ & $67.42^{\mathrm{d}}$ & 0.39 \\
\hline
\end{tabular}

$\overline{\mathrm{a}-\mathrm{f}}$ Means on the same row with different superscripts are significantly different $(\mathrm{p}<0.05) ; \mathrm{FENT}=100 \%$ Fresh Enterolobium cyclocarpum leaves; ENENT $=100 \%$ Ensiled Enterolobium cyclocarpum leaves; DENT $=100 \%$ Sundried Enterolobium cyclocarpum leaves; ENENT $75=75 \%$ Ensiled $+25 \%$ Sundried Enterolobium cyclocarpum leaves; ENENT 50 = 50\% Ensiled + 50\% SundriedEnterolobium cyclocarpum leaves; ENENT 25 = 25\% Ensiled + 75\% Sundried Enterolobium cyclocarpum leaves; SEM = Standard error of mean. NFE $=$ Nitrogen free extract.

The crude fibre values $(3.10-5.32 \%)$ obtained in this study for fresh and treated EC leaves were also significantly different $(p<0.05)$ across treatment. The highest $C F$ value was obtained in the dried EC leaves (Treatment 3 ). These $\mathrm{CF}$ values were within the range of values $(2.10-28.57 \%)$ reported by various authors for browse plants (Ahamefule et al., 2006; Asaolu et al., 2012; Isah et al., 2012; Ogunbosoye, 2013; Bassey et al., 2014; Galindo et al., 2014; Obua, 2014; Okpara et al., 2014; Oyedele et al., 2016). The CF value in this study for fresh EC is slightly higher than CF value of $2.10 \%$ reported by Ahamefule et al. (2006) for Alchornea cordifolia. However, the range of $\mathrm{CF}$ values obtained in this study is generally lower compared to $\mathrm{CF}$ values obtained by other authors for EC and other browse leaves. Babayemi (2006) reported a CF value of $48.20 \%$ for fresh EC leaves. Isah et al. (2011) reported a CF value of $8.16 \%$ for fresh Enterolobium cyclocarpum. In the case of other browse plants, Asaolu et al. (2012) reported a CF content of $12.16 \%$ for dried Leucaena 
leucocephala, while Oyedele et al. (2016) reported a CF value $16.37 \%$ for fresh leaves of Gliricidia sepium. Asaolu et al. (2012) on the other hand reported a CF value of $10.70 \%$ for dried Gliricidia sepium. Crude fibre values reported for fresh leaves of Moringa oleifera were $10.34 \%$ (Oyedele et al., 2016) and $14.04 \%$ (Tona et al., 2014). For dried leaves of Moringa oleifera, Asaolu et al. (2012) reported a $C F$ value of $11.03 \%$. The range of values obtained in this study for ether extract (EE) was 3.18 $4.71 \%$, with Treatment 4 (75\% ensiled + $25 \%$ dried Enterolobium cyclocarpum leaves combination) recording the highest value. The $\mathrm{EE}$ values were significantly different $(p<0.05)$ across treatments and were within the range of values $(0.50$ $28.40 \%)$ reported for browse plants. The following similar EE range of values obtained in this study was reported in literature: $2.21 \%$ (Isah et al., 2011) for EC leaves; $3.30 \%$ for Pentaclethra macrophyla (Obua, 2014) and $0.50 \%$ for Gmelina arborea (Okpara et al., 2014). Higher EE values than those obtained in this study reported in literature for browse plants include: $11.0 \%$ for Enterolobium cyclocarpum (Babayemi, 2006); 28.40\% for fresh Moringa oleifera (Oyedele et al., 2016); $14.58 \%$ for fresh Moringa oleifera leaves (Tona et al., 2014); 8.06\% for dried Moringa oleifera leaves (Asaolu et al., 2012); 6.25\% for Azadirachta indica (Isah et al., 2012); 6.67\% for Ficus exasperate leaves (Isah et al., 2012); 12.00\% for Gliricidia sepium (Ogunbosoye, 2013); $5.67 \%$ for dried Leucaena leucocephala leaves (Asaolu et al., 2012); $12.00 \%$ for fresh leaves of Leucaena leucocephala (Ogunbosoye, 2013); 10.10\% for Gmelina arborea (Ahamefule et al., 2006); 11.81\% for Spondias mombin, $10.34 \%$ for Manniophyton fulvum, $12.22 \%$ for Palisota hirsuta and $10.54 \%$ for Rauvolfia vomitoria (Bassey et al., 2014). Ash values of 4.40 -
$7.90 \%$, which were significantly different $(p<0.05)$ from each treatment were obtained for EC leaves in this study. Treatment 1 (100\% fresh EC leaves) had the least ash contents, while Treatment 3 (dried EC leaves) had the highest ash contents. The ash values recorded in this study was comparable to the values of $4.90 \%$ and $7.85 \%$ reported by Babayemi (2006) and Isah et al. (2011) respectively for the fresh leaves of Enterolobium cyclocarpum. The range of values for ash in this study was also within the range (2.20 $19.18 \%)$ reported for other browse plants (Ahamefule et al., 2006; Asaolu et al., 2012; Isah et al., 2012; Ogunbosoye, 2013; Bassey et al., 2014; Galindo et al., 2014; Obua, 2014; Okpara et al., 2014; Oyedele et al., 2016). The soluble carbohydrates (NFE) present in fresh and treated leaves of EC ranged from $65.74 \%$ in Treatment 3 (DENT) to $70.04 \%$ in Treatment 4 (ENENT 75). There were significant differences $(p<0.05)$ in NFE values across dietary treatment. The range of NFE values in this study was slightly higher than the $64.71 \%$ reported by Isah et al. (2011). The high NFE made it possible for EC leaves to be properly ensiled as a sole feedstuff. However, ensiling EC leaves with feedstuffs high in readily fermentable carbohydrates such as cassava peels will enhance its fermentation quality (Olorunnisomo and Fayomi, 2012; Ekanem et al., 2017).

Table 2 shows the fibre fractions of fresh and treated EC leaves. There were significant differences $(p<0.05)$ across the dietary treatments in all the fibre fractions assessed. Higher neutral detergent fibre (NDF) values $(56.64-57.92 \%)$ which were significantly different $(p<0.05)$ from each other were obtained. The highest NDF value was obtained for ensiled EC leaves (Treatment 2). The range of values for NDF reported in this study is within the range of 


\section{Effect of method of preservation on the chemical composition of Enterolobium cyclocarpum leaves}

$51.4-63.94 \%$ reported for fresh and dried EC leaves (Koenig et al., 2007; Galindo et al., 2014; Aderinboye et al., 2016). Similarly, the range of values (37.14 $39.87 \%$ ) for acid detergent fibre (ADF) obtained in this study agreed with values of 31.90 and $42.99 \%$ by Aderinboye et al. (2016) and Galindo et al. (2014) for fresh and 3-day sundried EC leaves respectively. High lignin contents (13.30 - 14.96\%) were also obtained.

Table 2: Fibre fractions (\%) of fresh and treated Enterolobium cyclocarpum leaves

\begin{tabular}{llllllll}
\hline Parameters & FENT & ENENT & DENT & ENENT 75 & ENENT 50 & ENENT 25 & SEM \\
\hline NDF & $57.86^{\mathrm{b}}$ & $57.92^{\mathrm{a}}$ & $56.64^{\mathrm{f}}$ & $57.73^{\mathrm{c}}$ & $57.59^{\mathrm{e}}$ & $57.65^{\mathrm{d}}$ & 0.10 \\
ADF & $39.37^{\mathrm{d}}$ & $39.87^{\mathrm{a}}$ & $37.14^{\mathrm{e}}$ & $39.58^{\mathrm{b}}$ & $39.47^{\mathrm{c}}$ & $39.56^{\mathrm{b}}$ & 0.22 \\
ADL & $14.83^{\mathrm{b}}$ & $14.96^{\mathrm{a}}$ & $13.30^{\mathrm{f}}$ & $14.25^{\mathrm{c}}$ & $14.18^{\mathrm{e}}$ & $14.21^{\mathrm{d}}$ & 0.13 \\
Hemicellulose & $18.49^{\mathrm{b}}$ & $18.05^{\mathrm{f}}$ & $19.50^{\mathrm{a}}$ & $18.15^{\mathrm{c}}$ & $18.12^{\mathrm{d}}$ & $18.10^{\mathrm{e}}$ & 0.12 \\
Cellulose & $24.54^{\mathrm{d}}$ & $24.91^{\mathrm{c}}$ & $23.85^{\mathrm{e}}$ & $25.33^{\mathrm{a}}$ & $25.29^{\mathrm{b}}$ & $25.34^{\mathrm{a}}$ & 0.13 \\
\hline
\end{tabular}

$\overline{\mathrm{a}-\mathrm{f}}$ Means on the same row with different superscripts are significantly different $(\mathrm{p}<0.05) ;$ FENT $=100 \%$ Fresh Enterolobium cyclocarpum leaves; ENENT $=100 \%$ Ensiled Enterolobium cyclocarpum leaves; DENT $=100 \%$ Sundried Enterolobium cyclocarpum leaves; ENENT $75=75 \%$ Ensiled $+25 \%$ Sundried Enterolobium cyclocarpum leaves; ENENT $50=50 \%$ Ensiled + 50\% Sundried Enterolobium cyclocarpum leaves; ENENT $25=25 \%$ Ensiled + $75 \%$ Sundried Enterolobium cyclocarpum leaves; SEM = Standard error of mean. NDF = Neutral detergent fibre ADF $=$ Acid detergent fibre. $\mathrm{ADL}=$ Acid detergent lignin.

The anti-nutritional factors present in fresh and treated EC leaves are as shown in Table 3. The fresh EC leaves were quite high in oxalic acid (450.21 mg/100g). Tannin was also present in higher concentrations (74.41 $-158.11 \mathrm{mg} / 100 \mathrm{~g}$ ) in both fresh and treated EC leaves. Saponin, phytate and HCN occurred in relatively low proportions in the fresh EC leaves. Apart from the contents of oxalate, there were significant differences $(p<0.05)$ in the anti-nutrients composition of fresh and treated EC leaves. The preservation of EC leaves either as silage, hay and silage-hay combinations drastically reduced the amounts of oxalic acid to the range of $234.10-315.14 \mathrm{mg} / 100 \mathrm{~g}$. Sun drying reduced the amount of oxalate quite lower $(288.13 \mathrm{mg} / 100 \mathrm{~g})$ in EC leaves compared to ensiling (315.14 mg/100g). However, the lowest concentration of oxalate $(234.10 \mathrm{mg} / 100 \mathrm{~g})$ was recorded for d 5 with the 50:50 silage/hay EC leaf combinations. On the other hand, the concentration of tannin, saponin, phytate and $\mathrm{HCN}$ varied with the differently treated EC leaves and treated leaves combinations. Ensiling significantly $(p<0.05)$ reduced the concentration of tannin, phytate and $\mathrm{HCN}$ compared to sun drying. Conversely, sun drying reduced the concentration of saponin compared to ensiling. Results obtained in this study showed that the different treatment methods reduced/affected the concentrations of the secondary plant metabolites but do not completely eliminate them. This is in line with the findings of Heckendon et al. (2006) who reported that despite the conditions experienced during the drying of the leaves of the sainfoin browse plants to hay, the hay still contained significant bioactive properties similar to those in the fresh leaves. Similarly, Stewart (2018) also reported significant concentrations of condensed tannins in some non-popular browse leaves hays when she determined the effect of tannin-containing legume hays on enteric methane emissions and nitrogen partitioning in beef cattle. Higher concentrations of tannins are desirable in ruminant nutrition because of their reported beneficial effect such as tannin-protein binding with increased protein flow into the duodenum, partitioning more nitrogen 
excretion to feaces rather than urine and reducing methanogenesis (Carulla et al.,
2005; Mueller-Harvey, 2006; Maamouri et al., 2011; Aguerre et al., 2015; Stewart, 2018).

Table 3: Anti-nutritional factors (mg/100g) of fresh and treated Enterolobium cyclocarpum leaves

\begin{tabular}{llllllll}
\hline Parameters & FENT & ENENT & DENT & ENENT 75 & ENENT 50 & ENENT 25 & SEM \\
\hline Tannin & $93.40^{\mathrm{c}}$ & $74.41^{\mathrm{e}}$ & $75.97^{\mathrm{d}}$ & $158.11^{\mathrm{a}}$ & $74.59^{\mathrm{e}}$ & $130.73^{\mathrm{b}}$ & 7.81 \\
Saponin & $3.92^{\mathrm{c}}$ & $4.30^{\mathrm{b}}$ & $3.18^{\mathrm{f}}$ & $3.80^{\mathrm{d}}$ & $4.49^{\mathrm{a}}$ & $3.64^{\mathrm{e}}$ & 0.10 \\
Oxalate & $450.21^{\mathrm{d}}$ & $315.14^{\mathrm{c}}$ & $288.13^{\mathrm{bc}}$ & $276.12^{\mathrm{abc}}$ & $234.10^{\mathrm{a}}$ & $253.30^{\mathrm{ab}}$ & 17.76 \\
Phytate & $3.60^{\mathrm{e}}$ & $2.51^{\mathrm{f}}$ & $3.96^{\mathrm{d}}$ & $89.90^{\mathrm{a}}$ & $81.48^{\mathrm{b}}$ & $80.84^{\mathrm{c}}$ & 9.81 \\
HCN & $6.10^{\mathrm{e}}$ & $4.50^{\mathrm{f}}$ & $11.70^{\mathrm{c}}$ & $15.90^{\mathrm{b}}$ & $10.27^{\mathrm{d}}$ & $19.96^{\mathrm{a}}$ & 1.29 \\
\hline
\end{tabular}

$\overline{\mathrm{a}-\mathrm{d}}$ Means on the same row with different superscripts are significantly different $(\mathrm{p}<0.05)$; FENT $=100 \%$ Fresh Enterolobium cyclocarpum leaves; ENENT $=100 \%$ Ensiled Enterolobium cyclocarpum leaves; DENT $=100 \%$ Sundried Enterolobium cyclocarpum leaves; ENENT $75=75 \%$ Ensiled $+25 \%$ Sundried Enterolobium cyclocarpum leaves; ENENT 50 = 50\% Ensiled + 50\% Sundried Enterolobium cyclocarpum leaves; ENENT $25=25 \%$ Ensiled + $75 \%$ Sundried Enterolobium cyclocarpum leaves; SEM = Standard error of mean. HCN = Hydrocyanide.

Table 4 shows the mineral composition of fresh, ensiled, sundried and combinations of ensiled and sundried EC leaves. The EC leaves were quite high in the macro mineral compositions. The mineral contents in EC leaves obtained in this study were within the range needed for adequate physiological growth, reproduction and milk production of West African dwarf sheep and goats. The calcium: phosphorus ratio was within the recommended 1:1 level. Most of the macro mineral contents obtained in this study were within the range of values reported by Babayemi (2006) and Galindo et al. (2014). The slight variations in the concentrations of some macro minerals obtained in this study compared to that reported by Babayemi (2006) and Galindo et al. (2014) for fresh and dried EC leaves respectively may be due to soil type, climatic conditions and method of analyses.

Table 4: Mineral composition (\%) of fresh and treated Enterolobium cyclocarpum leaves

\begin{tabular}{|c|c|c|c|c|c|c|c|}
\hline Parameters & FENT & ENENT & DENT & ENENT 75 & ENENT 50 & ENENT 25 & SEM \\
\hline Calcium & $0.24^{\mathrm{bc}}$ & $0.26^{\mathrm{a}}$ & $0.23^{\mathrm{cd}}$ & $0.25^{\mathrm{ab}}$ & $0.22^{\mathrm{d}}$ & $0.22^{\mathrm{d}}$ & 0.00 \\
\hline Phosphorus & $0.33^{\mathrm{ab}}$ & $0.34^{\mathrm{a}}$ & $0.32^{\mathrm{bc}}$ & $0.33^{\mathrm{ab}}$ & $0.32^{\mathrm{bc}}$ & $0.31^{\mathrm{c}}$ & 0.00 \\
\hline Potassium & $0.63^{b c}$ & $0.65^{\mathrm{a}}$ & $0.63^{\mathrm{bc}}$ & $0.64^{\mathrm{ab}}$ & $0.62^{c}$ & $0.59^{d}$ & 0.01 \\
\hline Magnesium & $0.28^{\mathrm{a}}$ & $0.29^{a}$ & $0.26^{b}$ & $0.28^{\mathrm{a}}$ & $0.25^{\mathrm{bc}}$ & $0.24^{c}$ & 0.01 \\
\hline Sodium & $0.17^{\mathrm{bc}}$ & $0.19^{\mathrm{a}}$ & $0.16^{\mathrm{c}}$ & $0.18^{\mathrm{ab}}$ & $0.16^{\mathrm{c}}$ & $0.13^{\mathrm{d}}$ & 0.01 \\
\hline
\end{tabular}

The vitamin contents of fresh and treated EC leaves are shown in Table 5. There were significant differences $(p<0.05)$ in the concentration of vitamin A, C, D and E of the EC leaves. Concentration of vitamin A was highest in the sundried EC leaves while vitamin $\mathrm{D}$ was highest in the ensiled leaves. Concentrations of vitamin $\mathrm{C}$ was generally higher in the preserved leaves (Treatment 2 - 6), with highest value obtained in Treatment 4 (ensiled 75 : hay $25 \%$ ). 
Effect of method of preservation on the chemical composition of Enterolobium cyclocarpum leaves

Table 5: Vitamin contents $(\mathrm{mg} / 100 \mathrm{~g})$ of fresh and treated Enterolobium cyclocarpum leaves

\begin{tabular}{llllllll}
\hline Parameters & FENT & ENENT & DENT & ENENT 75 & ENENT 50 & ENENT 25 & SEM \\
\hline Vitamin A & $1.44^{\mathrm{e}}$ & $1.02^{\mathrm{f}}$ & $2.39^{\mathrm{a}}$ & $1.82^{\mathrm{c}}$ & $2.09^{\mathrm{b}}$ & $1.61^{\mathrm{d}}$ & 0.11 \\
Vitamin C & $308.79^{\mathrm{f}}$ & $489.40^{\mathrm{d}}$ & $613.40^{\mathrm{c}}$ & $657.60^{\mathrm{a}}$ & $626.33^{\mathrm{b}}$ & $444.21^{\mathrm{e}}$ & 29.74 \\
Vitamin D $^{\mathrm{a}}$ & $57.96^{\mathrm{c}}$ & $58.85^{\mathrm{a}}$ & $55.67^{\mathrm{d}}$ & $58.72^{\mathrm{b}}$ & $55.48^{\mathrm{e}}$ & $53.96^{\mathrm{f}}$ & 0.45 \\
Vitamin E & $22.18^{\mathrm{a}}$ & $17.33^{\mathrm{c}}$ & $13.10^{\mathrm{e}}$ & $11.28^{\mathrm{f}}$ & $13.78^{\mathrm{d}}$ & $20.10^{\mathrm{b}}$ & 0.95 \\
\hline
\end{tabular}

$\overline{\mathrm{a}-\mathrm{f}}$ Means on the same row with different superscripts are significantly different $(\mathrm{p}<0.05)$; FENT $=100 \%$ Fresh Enterolobium cyclocarpum leaves; ENENT $=100 \%$ Ensiled Enterolobium cyclocarpum leaves; DENT $=100 \%$ Sundried Enterolobium cyclocarpum leaves; ENENT $75=75 \%$ Ensiled $+25 \%$ Sundried Enterolobium cyclocarpum leaves; ENENT 50 = 50\% Ensiled + 50\% Sundried Enterolobium cyclocarpum leaves; ENENT 25 = 25\% Ensiled + $75 \%$ Sundried Enterolobium cyclocarpum leaves; SEM = Standard error of mean.

\section{Conclusion}

Ensiling and sun drying affected the proximate, fibre fractions, minerals and vitamins composition of EC leaves. However, the CP contents in the fresh and preserved EC leaves were higher than the minimum protein requirements for ruminant animals. Ensiling and sun drying reduced the contents of anti-nutritional factors in EC leaves but do not completely eliminate them. Ensiling reduced the concentrations of condensed tannins, phytate and HCN in EC leaves compared to sun drying. On the other hand, sun drying reduced the concentration of saponin in EC leaves. Concentrations of vitamins and minerals in both the fresh and treated leaves were within range for normal physiological functions of farm animals.

\section{References}

Aderinboye, R. Y., Akinlolu, A. O., Adeleke, M. A., Najeem, G. O., Ojo, V. O. A., Isah, O. A. and Babayemi, O. J. 2016. In vitro gas production and dry matter degradation of four browse leaves using cattle, sheep and goat inocula. Slovakian Journal of Animal Science. 49 (1): 32-43.

Aguerre, M. J., Capozzolo, M. C., Lencioni, P., Cabral, C. and Wattiaux, M. A. 2015. Effect of quebracho-chestnut tannin extracts at 2 dietary crude protein levels on performance, rumen fermentation, and nitrogen partitioning in dairy cows. Journal of Dairy Science. 99: 4476 - 4486.

Ahamefule, F. O., Obua, B. E., Ibeawuchi, J. A. and Udosen, N. R. 2006. The nutritive value of some plants browsed by cattle in Umudike, Southeastern Nigeria. Pakistan Journal of Nutrition. 5 (5): $404-409$.

Andreu, M. G., Friedman, M. H., Northrop, R. J. 2015. Enterolobium cyclocarpum, Ear Tree. FOR 304, School of Forest Resources and Conservation Department, UF/IFAS Extension.

AOAC. 1980. Official methods of Analysis, $13^{\text {th }}$ edition. Association of Official Analytical Chemists, Washington, D.C. 19: 132 - 136.

AOAC. 1990. Official methods of analysis $15^{\text {th }}$ ed. Association of Analytical Chemist. Washington DC. Pp. $69-$ 88.

ARC. 1984. The nutrient Requirements of Ruminant Livestock. Supplement no 1. Commonwealth agricultural bureaux, Slough, UK.

Asaolu, V., Binuomote, R., Akinlade, J., Aderinola, O. and Oyelami, $O$. 2012. Intake and growth performance of West African dwarf goats fed Moringa oleifera, Gliricidia sepium and Leucaena leucocephala dried leaves as supplements to cassava peels. 
Journal of Biology, Agriculture and Healthcare. 2(10):76 - 88.

Babayemi, O. J. 2006. Anti-nutritional factors, nutritive value and in vitro gas production of foliage and fruit of Enterolobium cyclocarpum. World Journal of Zoology. 1 (2): 113 - 117

Babayemi, O. J. 2009. Silage quality, dry matter intake and digestibility by African dwarf Sheep of Guinea grass (Panicum maximum $c v$ ntchisi) harvested at 4 and 12 week regrowths. African Journal of Biotechnology. 8: 3988 - 3989.

Bassey, M. E., Peters, A. A., Etuk, G. E. and Udoh, T. B. 2014. Indigenous browse plants used for goat production in Akwa Ibom state, Nigeria; their phytochemical, mineral, nutrient and anti-nutrients contents. International Journal of Plant and Soil Science. 3(9): $1130-$ 1142.

Broderick, G. A. and Albretch, K. A. 1997. Ruminal in vitro degradation of protein in tannin-free and tannincontaining forage legume species. Crop Science. 37: 1884-1891.

Carulla, J. E., Kreuzer, M., Machmuller, A. and Hess, H. D. 2005. Supplementation of Acacia mearnsii tannins decreases methanogenesis and urinary nitrogen in forage-fed sheep. Australian Journal of Agricultural Research. 56: $961-970$.

Crozier A., Clifford, M. N. and Ashihara, H. 2006. Plant secondary metabolites: occurrence, structure and role in the human diet. Blackwell Publishing, Oxford, UK, Ames, Iowa, xii. Pp. 372.

Demain, A. L. and Fang, A. 2000. The natural functions of secondary metabolites. Advances in

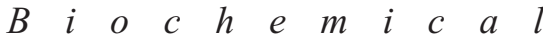

Engineering/Biotechnology. 69:1 39.

Ekanem, N. J., Olorunnisomo, O. A., Ikwenze, K., Mbaba, E. N. and Ifut, O. J. 2017. $\mathrm{pH}$, fermentation pathways and physical characteristics of cassava peels supplemented and ensiled with brewers' dried grains and poultry litter. Nigerian Journal of Agriculture, Food and Environment. 13 (3): 7-10.

Falola, O. O., Alasa, M. C. and B a b a ye mi, O. J . 2013 . Assessment of silage quality and forage acceptability of vetiver grass (Chrysopogon zizanioides L. Roberty) ensiled with cassava peels by WAD goat. Pakistan Journal of Nutrition. 12 (6): 529 533.

Galindo, J., González, N., Marrero, Y., Sosa, A., Ruiz, T., Febles, G., Torres, V., Aldana, A. I., Achang, G., Moreira, O. Sarduy, L. and Noda, A. C. 2014. Effect of tropical plant foliage on the control of methane production and in vitro ruminal protozoa population. Cuban Journal of Agricultural Science. 48 (4): 359 364.

Harborne, J. B. 1973. Phytochemical methods. Chapman and Hill, London. ( $1^{\text {st }}$ ed.), Pp. 288-290.

Heckendon, F., Haring, D. A., Maurer, V., Zinsstag, J., Langhans, W. and Hertzberg, H. 2006. Effect of sainfoin (Onobrychis viciifolia) silage and hay on established populations of Haemonchus contortus and Cooperia curticei in lambs. Veterinary Parasitology. 142: 293 - 300.

Ifut, O.J, and Mbaba, E.N. 2014. Effect of brewer's spent grain supplement on 
Effect of method of preservation on the chemical composition of Enterolobium cyclocarpum leaves

the utilization of mixed forages by West African dwarf goat. Nigerian Journal of Agriculture, Food and Environment. 10(4): 87 - 89.

Isah O. A., Fayemi P. O., Gazaly M. B. and Aderinboye, R. Y. 2012. Nutritional characteristics of four browse plants consumed by freeranging ruminants in Western part of Nigeria. African Journal of Agricultural Research. 7(12): 1944 -1949 .

Isah, O. A., Aderinboye, R. Y. and Enogieru, V. A. 2011. Effect of anti-nutritional factors on rumen bacteria of West African dwarf goats fed tropical browse species and crop by-products. Journal of Agricultural Science and Environment. 11(1): 50 - 58.

Koenig, K. M., Ivan, M., Teferedegne, B. T., Morgavi, D. P., Rode, L. M., Ibrahim, I. M. and Newbold, C. J. 2007 . Effect of dietary Enterolobium cyclocarpum on microbial protein flow and nutrient digestibility in sheep maintained fauna-free, with total mixed fauna or with Entodinium caudatum monofauna. British Journal of Nutrition. 98: 504-516.

Maamouri, O., Atti, A., Kraiem, K. and Mahouachi, M. 2011. Effects of concentrate and Acacia cyanophylla foliage on nitrogen balance and milk production for grazing ewes. Livestock Sciences. 139:264 - 270 .

McCance, R. A. and Widdowson, E. M. 1953. Phytins in human nutrition. Biochemistry Journal. 29B. 2694 2699.

McDonald, P., Edward, R. A. and Greenhalgh, J. F. D. 1995. Animal nutrition, $5^{\text {th }}$ Ed. Longman Scientific and Technical, England.

Mueller-Harvey, I. 2006. Unravelling the conundrum of tannins in animal nutrition and health. Journal of Science, Food and Agriculture. 86:2010-2037.

Norton, B. W. 1998. The nutritive value of tree legumes. In: Gutteridge, R .C. and Shelton, H. M. (Eds.), forage trees legumes in tropical agriculture. Tropical Grassland Society of Australia Inc., St Lucia Queensland.

Obua, B. E. 2014. Survey of the diversity and proximate composition of selected most preferred browse plants utilized for goat feeding in Imo and Enugu states of Southeastern Nigeria. International Journal of Agriculture and Rural Development. 17 (3): 1947 - 1958.

Ogunbosoye, D. O. 2013. Correlation between milk composition and kids growth of West African dwarf (WAD) goat fed forage based diet in Southwest Nigeria. Global Veterinaria. 11 (2): 155 - 159.

Okpara, O., Akporhuarho, P. O. and Ok a gba re, G. O. 2014 . Determination of browse intake and nutrient digestibility of grazing West African dwarf (WAD) goats fed varying levels of Gmelina arborea leaves as supplements in Delta State Nigeria. International Journal of Animal and Veterinary Advances. 6(2): 52 - 57.

Olorunnisomo, O. A. and Fayomi, O. H. 2012. Quality and preference of zebu heifers for legume or elephant grass-silages with cassava peel. Livestock Research for Rural Development. Volume 24 Article $\begin{array}{lllll}\text { \# } & 1 & 6 & 8\end{array}$ http://www.lrrd.org/lrrd24/9/olor2 4168.htm. Accessed January 25, 
2018

Orwa, C., Mutua, A., Kindt, R., Jamnadass, R. and Anthony, S. 2009. Agroforestree Database: a tree reference and selection guide $\mathrm{v}$ e $\mathrm{r}$ s i o $\mathrm{n} 4$. 0 (http://www.worldagroforestry.org /sites/treedbs/ treedatabases.asp). Accessed March 23, 2018.

Oyedele, O. J., Asaolu, V. O. and Odeyinka, S. M. 2016. Nutrient digestibility and growth performance of West African dwarf (WAD) goats fed foliage combinations of Moringa oleifera and Gliricidia sepium with equal proportions of a low-cost concentrate. Journal of Natural Sciences Research. 6(18): 20 - 29.

Pearson, D. A. 1976. Chemical Analysis of Foods. $7^{\text {th }}$ Ed. Churchill Livingstone. Edinburgh.

SAS (Statistical Analysis System). 2000. SAS/STAT User's guide, SAS Institute Inc. Cary, North Carolina, USA.

Soliva, C. R. 2007. Plant secondary metabolites in ruminant nutrition: potentials and risk. 6 BokuSymposium Tierernahrung. Pp. 33 $-41$.

Stewart, E. K. 2018. Effect of TanninContaining Legume Hays on Enteric Methane Emissions and Nitrogen Partitioning in Beef Cattle. All Graduate Theses and Dissertations. 7170 . https://digitalcommons.usu.edu/et d/7170. Retrieved on March 07, 2018 .
Tona, G. O., Ogunbosoye, D. O. and Bakare, B. A. 2014. Growth performance and nutrient digestibility of West African Dwarf goats fed graded levels of Moringa oleifera leaf meal. International Journal of Current Microbiology and Applied Sciences. 3(8): 99 106.

Van Soest, P., Robertson, J. B. and Lewis, B. A. 1991. Methods for dietary fibre, neutral detergent fibre as non-starch polysaccharides in relation to animal nutrition. Journal of Dairy Science. 74: 3583 $-3597$.

Waghorn, G. 2008. Beneficial and detrimental effects of condensed tannins for sustainable sheep and goat production - progress and challenges. Animal Feed Science Technology. 147: 116 - 139.

Wikipedia, the Free Encyclopedia 2018. Enterolobium cyclocarpum. https://en.wikipedia.org/wiki /Enterolobium cyclocarpum. Accessed March 23, 2018.

Received: $17^{\text {th }}$ October, 2019 Accepted: $19^{\text {th }}$ January, 2020 